\title{
PATHOGENICITY OF Entamoeba dispar UNDER XENIC AND MONOXENIC CULTIVATION COMPARED TO A VIRULENT E. histolytica
}

\author{
Adriana Oliveira COSTA(1), Maria Aparecida GOMES(2), Orivaldo Alves ROCHA(3) \& Edward Felix SILVA(2)
}

\section{SUMMARY}

Two xenic isolates and cloned cultures of Entamoeba dispar were submitted to monoxenization using Crithidia fasciculata as the associated organism. Growth in monoxenic cultivation and ability of xenic and monoxenic trophozoites to destroy VERO cells and produce lesions in hamster livers were compared to those of a virulent $E$. histolytica. Parental and cloned E. dispar under monoxenic cultivation showed a remarkable lower growth than the monoxenic E. histolytica and were avirulent in both in vivo and in vitro tests. When xenically cultured, trophozoites of $E$. dispar showed a moderate lytic activity against VERO cells (1.5 to $41.8 \%$ of destruction) but caused severe hepatic lesions in hamsters as those caused by the virulent E. histolytica (29 to $100 \%$ in prevalence and 0.86 to 4.00 in lesion degree). Although $E$. dispar has not been associated with invasive disease in men, the ability of xenic trophozoites to produce prominent tissue damage in experimental conditions has indicated that some strains have a considerable pathogenic potential when in presence of bacteria.

KEYWORDS: Entamoeba dispar; Entamoeba histolytica; Cultivation; Pathogenicity.

\section{INTRODUCTION}

The existence of Entamoeba dispar, a species morphologically similar to E. histolytica, was first proposed by BRUMPT in $1925^{4}$ to explain asymptomatic cases of amoebiasis. Most researchers, however, rejected this idea at that time, mainly because the proposed organism could not be differentiated from E. histolytica. Some decades later, studies on the isoenzymatic profile (zymodemes) of several isolates ${ }^{22,23}$ allowed E. histolytica to be classified into pathogenic and nonpathogenic forms. Correlation of zymodemes with other biological and molecular data ${ }^{8}$ led researchers to reconsider Brumpt's theory. The non-pathogenic form of $E$. histolytica was then renamed $E$. dispar, a non-invasive parasite of the human gut $^{28}$.

It is known that under certain conditions E. dispar may be pathogenic ${ }^{8}$, based on studies that demonstrated trophozoites ability to produce focal lesions in experimental animals ${ }^{6,27}$. A moderate lytic activity of an axenic $E$. dispar strain was also detected ${ }^{11}$. Nevertheless, studies on $E$. dispar pathogenicity remain scarce. Isolation of new $E$. dispar strains is necessary for a better characterization of this species.

In the present study, two xenically cultured $E$. dispar isolates and cloned cultures obtained from them were subjected to monoxenization using Crithidia fasciculata as the associated organism. Growth of monoxenic trophozoites, cytopathic effect and ability to produce lesions in hamster livers of either xenic and monoxenic cultures were compared to a virulent isolate of E. histolytica.

\section{MATERIAL AND METHODS}

Parasites: The Entamoeba isolates ICB-MGL2 (MGL2) and ICB$\mathrm{ADO}(\mathrm{ADO})$ were obtained from cysts from an asymptomatic carrier and a symptomatic patient, respectively, both residents in Brazil. A physician examined the symptomatic patient in order to determine the clinic form. Cultures were established xenically in Pavlova's medium modified by SILVA ${ }^{13}$ with bacterial flora. As soon as sufficient growth had occurred, trophozoites were grown in culture flasks to produce lysates for isoenzyme typing ${ }^{22}$. Genetic identification was also confirmed by polymerase chain reaction through analyses of conformational polymorphism in the 482 bp fragment, as previously described $^{14}$. Trophozoites of each isolate were cloned using a dilution method $^{26}$ and the clones ADO-A3, ADO-B3 and MGL2-A3 were used in the experiments. The same bacterial flora from the parental strains was maintained in the clones. The E. histolytica strain ICB-EGG (zymodeme XIX), used as the virulent reference strain, was obtained from a symptomatic patient ${ }^{24}$.

Monoxenization: Trophozoites of xenic cultures were washed three times in sterile PBS (pH 7.2) and transferred to YI-S medium ${ }^{9}$ containing Crithidia fasciculata as the associated organism (C. fasciculata 
COSTA, A.O.; GOMES, M.A.; ROCHA, O.A. \& SILVA, E.F. - Pathogenicity of Entamoeba dispar under xenic and monoxenic cultivation compared to a virulent E. histolytica. Rev. Inst. Med. trop. S. Paulo, 48(5): 245-250, 2006.

Anopheles American Type Culture Collection [ATCC] Accession Number 11745, stock maintained in YI-S at room temperature). Bacteria were eliminated by addition of ceftazidime (Fortaz ${ }^{\circledR}$, Glaxo Wellcome), ofloxacin (Floxtat ${ }^{\circledR}$, Janssen-Cilag) or amicacine sulphate (Amicacin ${ }^{\circledR}$, Neoquimica) to the medium at final concentrations of $660 \mu \mathrm{g} / \mathrm{mL}$, $40 \mu \mathrm{g} / \mathrm{mL}$ and $333 \mu \mathrm{g} / \mathrm{mL}$, respectively. Antibiotic use was halted when absence of bacteria was confirmed by microbiological assays. Viable C. fasciculata was added only on the day of sub-culturing. Monoxenic samples were also submitted to isoenzyme typing and analysis of conformational polymorphism in the 482 bp fragment ${ }^{14}$.

Growth curves: After more than a year of monoxenic cultivation, the growth of Entamoeba was compared. Sixteen to 18 tubes containing $6.5 \mathrm{~mL}$ of YI-S medium were inoculated with 700 trophozoites $/ \mathrm{mL}$ and $1.4 \times 10^{6}$ forms of Crithidia fasciculata. Every 24 hours, trophozoites from two tubes were quantified and the average was recorded. Growth curves were delineated with the average of three independent experiments. Differences in growth among the samples were evaluated by the Kruskal-Wallis test.

Cytopathic effect: The cytopathic effect of trophozoites on VERO cells monolayers was measured by a quantitative assay ${ }^{3}$. Briefly, confluent VERO cells monolayers $\left(2 \times 10^{5}\right.$ cells $)$ were incubated for one $\mathrm{h}$ at $37{ }^{\circ} \mathrm{C}$ in a $5 \% \mathrm{CO}_{2}$ atmosphere with $1 \times 10^{5}$ trophozoites washed twice in PBS (pH 7.2) and transferred to DMEM (Dulbecco's Modified Eagle Medium). The interaction was stopped by ice bath for $10 \mathrm{~min}$, the wells were carefully washed with cold saline, the remaining cells were fixed with $4 \%$ formaldehyde for $10 \mathrm{~min}$ and washed again with saline (two times). Methylene blue $0.1 \%$ in borate buffer $(0.1 \mathrm{M}$ $\mathrm{pH}$ 8.9) was added to the wells to stain the cells for $10 \mathrm{~min}$. The wells were washed three times with borate buffer and the stain of each well was extracted with $1 \mathrm{~mL}$ of $\mathrm{HCl} 0.1 \mathrm{M}$. The solution was spectrophotometrically measured at $660 \mathrm{~nm}$; the dye extracted from cells that did not interact with trophozoites ( $0 \%$ of destruction) was used as control. The bacterial flora of each xenic strain (seeded in 10 $\mathrm{mL}$ of Pavlova medium, grown for 24 hour at $37{ }^{\circ} \mathrm{C}$ ) and $C$. fasciculata ( 1 x $10^{6}$ grown in YI-S medium) were also tested. The Kruskal-Wallis test was used to determine the significance of differences in the destruction.

Hepatic inoculation in hamsters: Thirty-day-old hamsters (Mesocricetus auratus) obtained from a biotery (Biotério do Departamento de Parasitologia ICB/UFMG, Belo Horizonte, Brazil) were anesthetized with sodium pentobarbital and subjected to laparotomy. Trophozoites $\left(2.5 \times 10^{5}\right.$ or $\left.5.0 \times 10^{5}\right)$ washed twice in PBS $(\mathrm{pH}$ 7.2) were inoculated directly into the left lobe of the liver. Bacterial flora (seeded in $10 \mathrm{~mL}$ of Pavlova medium, grown for 24 hour at $37^{\circ} \mathrm{C}$ ) and $C$. fasciculata ( $1 \times 10^{6}$ grown in YI-S medium) were inoculated separately as controls. Animals were sacrificed six days later and results were determined by prevalence (number of animals with lesions divided by number of animals inoculated, expressed as a percentage) as well as the individual and average severity of lesions, based on criteria described previously ${ }^{10}$, with some modifications. Fragments of the lesion were inoculated into culture medium or macerated in PBS for microscopic examination in order to confirm the presence of amoebae. Fixation and processing for haematoxylin and eosin staining (H\&E) were performed to allow histopathological examination of the material. Statistical significance of prevalence and severity of lesions were determined by Pearson's $\mathrm{X}^{2}$ and Kruskal-Wallis tests, respectively.

\section{RESULTS}

Zymodeme, specific characterization by PCR and clinical form of the subjects from whom the strains were isolated are shown in Table 1. Complete monoxenization of E. dispar and E. histolytica cultures was accomplished after treatment with antibiotics for three or four days. At this stage, the majority of trophozoites was rounded and did not attach to the glass of the culture tubes. After approximately two months, the monoxenic cultures became stable and trophozoites multiplied adhered to the glass. Cultures did not grow in YI-S without $C$. fasciculata, even after a year had passed. No alterations in the zymodemes of the parental and cloned E. dispar were detected after monoxenization, and neither did the amplification profile $482 \mathrm{pb}$ fragment vary (Fig. 1).

Table 1

Entamoeba dispar and E. histolytica isolates

\begin{tabular}{lllll}
\hline Isolate & Species $^{\text {a }}$ & Zymodeme & Origin & Clinical form $^{\text {b }}$ \\
\hline ADO & E. dispar & I & Brazil & NDC \\
MGL2 & E. dispar & I & Brazil & Asymptomatic \\
EGG & E. histolytica & XIX & Brazil & DC, HA \\
\hline
\end{tabular}

${ }^{a}$ Genetic identification by conformational polymorphism in the 482 bp gene;

${ }^{b}$ NDC: non dysenteric colitis; DC: dysenteric colitis; HA: hepatic abscess.

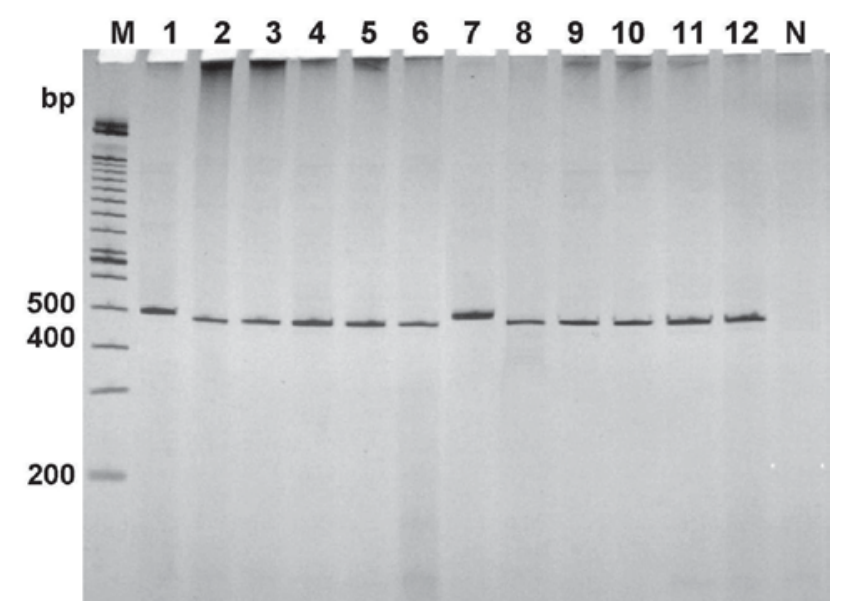

Fig. 1 - Silver-stained 5\% polyacrylamide gel electrophoresis showing the conformational polymorphism of a 482 bp fragment amplified in strains of Entamoeba histolytica (EGG) and E. dispar. M- $100 \mathrm{~Kb}$ ladder, 1- EGG xenic, 2- ADO xenic, 3- ADO-A3 xenic, 4- ADO-B3 xenic, 5- $\mathrm{MGL}_{2}$ xenic, 6- $\mathrm{MGL}_{2}$-A3 xenic, 7- EGG monoxenic, 8- ADO monoxenic, 9- ADO-A3 monoxenic, 10- ADO-B3 monoxenic, 11- $\mathrm{MGL}_{2}$ monoxenic, 12- $\mathrm{MGL}_{2}-\mathrm{A} 3$ monoxenic, N- Control without DNA.

Exponential growth of monoxenic cultures is represented in Fig. 2. After 48 hours of cultivation, the E. histolytica EGG strains surpassed the $E$. dispar strains, the difference reaching a significant point at 72 hours, a significance level of $10 \%(\mathrm{p}=0.089)$. While the E. dispar strains suffered growth decrease between 48 and 72 hours, the EGG $E$. histolytica kept its exponential growth until 120 hours of cultivation. 
COSTA, A.O.; GOMES, M.A.; ROCHA, O.A. \& SILVA, E.F. - Pathogenicity of Entamoeba dispar under xenic and monoxenic cultivation compared to a virulent E. histolytica. Rev. Inst. Med. trop. S. Paulo, 48(5): 245-250, 2006.

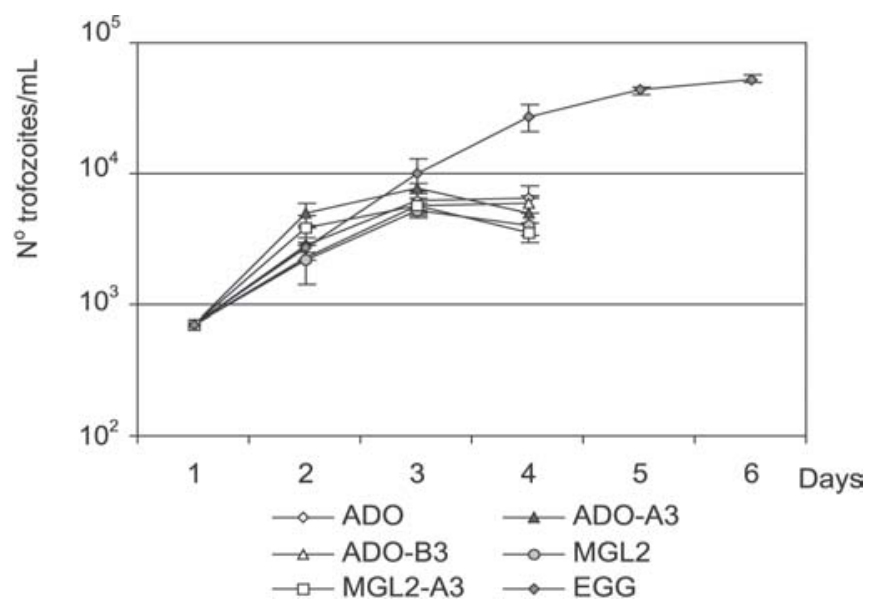

Fig. 2 - Growth curves of the Entamoeba dispar and E. histolytica (EGG) strains, in monoxenic cultivation with Crithidia fasciculata in YI-S medium, with initial inocula of 700 trophozoites/ $\mathrm{mL}$.

There was no significant growth difference when the E. dispar original and cloned strains were compared.

Most xenic E. dispar cultures presented a low to mild lytic activity against VERO cells (1.5 to $41.8 \%$ destruction), whereas the monoxenic cultures caused very little or no damage (Fig. 3). Destruction rates of E. dispar were significantly lower than those of E. histolytica, regardless the culture condition $(\mathrm{p}<0.05)$. Bacterial flora or C. fasciculata alone did not destroy VERO cells.

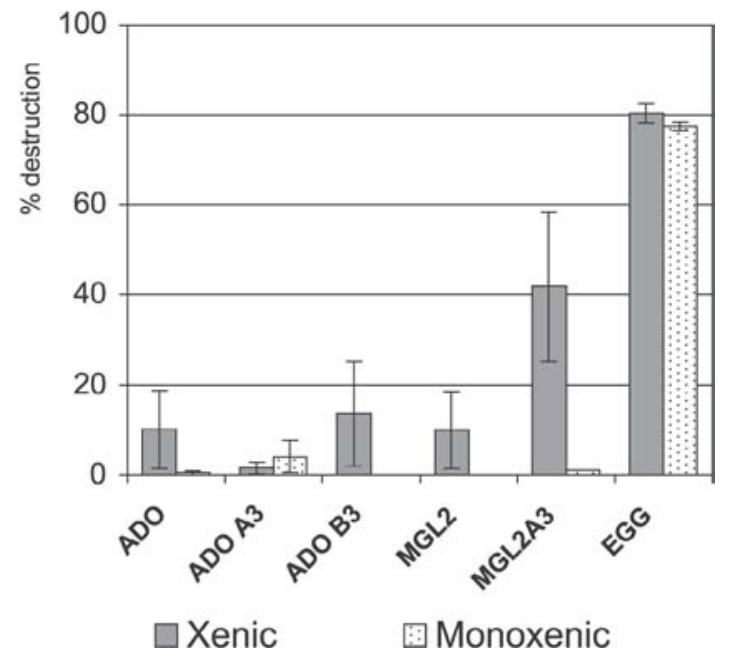

Fig. 3 - Cytopathic effect against VERO cells of Entamoeba dispar cultures under xenic and monoxenic cultivation in comparison to an E. histolytica strain (EGG).

Xenically cultivated trophozoites of both E. histolytica and E. dispar were able to produce lesions in hamster livers, with variable prevalence and severity (Table 2). Parental xenic strains of E. dispar showed similar prevalence and lesion grades $(\mathrm{p}=0.396)$ to those of the xenic strain of $E$. histolytica and higher values than their respective clones $(\mathrm{p}<0.05)$. Macroscopically, the lesions caused by xenic E. histolytica and E. dispar were similar, characterized by a yellowish necrotic area with a friable aspect. Microscopic examination of unfixed fragments revealed the presence of bacteria and motile trophozoites, the lesions being characterized as mixed. H\&E stained slides demonstrated areas with complete destruction of parenchyma and predominantly chronic inflammatory infiltrate on the border between necrotic and preserved parenchymal tissue (Figs. 4 A-B). Trophozoites were barely detected in $\mathrm{H} \& \mathrm{E}$ slides of xenic $E$. dispar, whereas they were abundant in slides of xenic E. histolytica (Fig. 4 C). Hamsters inoculated with bacterial flora presented normal livers or bacterial lesions smaller than $4 \mathrm{~mm}$ in diameter, limited by a fibroid wall enclosing purulent material (Fig. 4 D); perivascular and periportal, predominantly chronic, infiltrate was observed in less damaged areas of tissue.

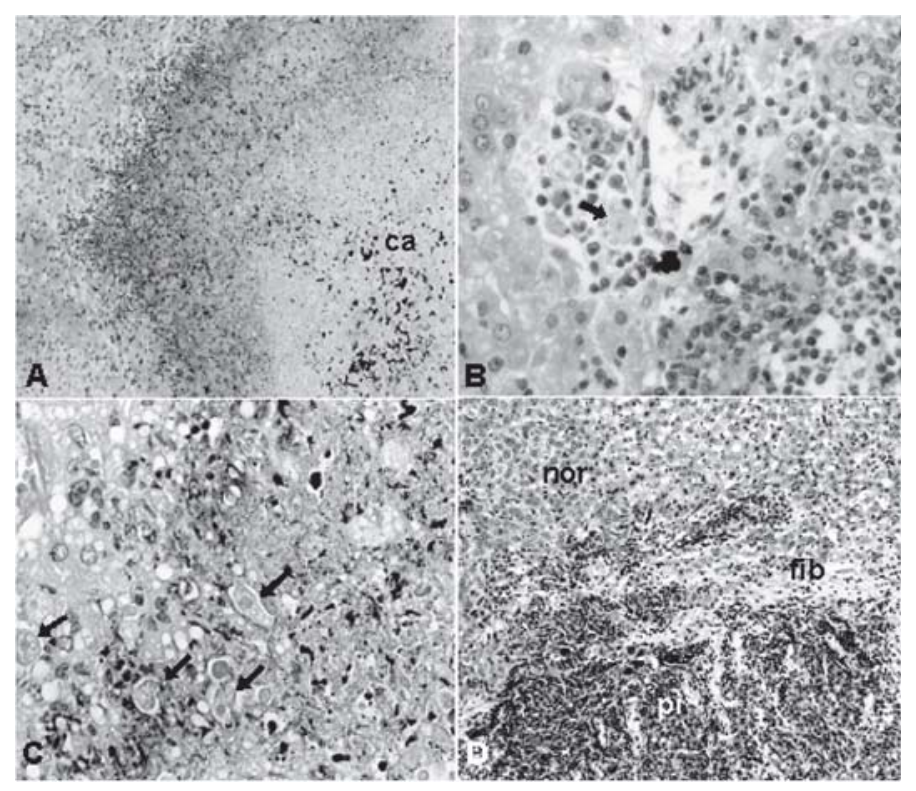

Fig. 4 - Histopathological aspects of hepatic lesions in hamster. A) Necrotic area and calcification foci (ca) of liver inoculated with a xenic E. dispar strain ADO. 100X. B) Inoculation with a xenic $E$. dispar (strain $\mathrm{MGL}_{2}$ ). Detail of an area between the normal parenchyma and necrotic focus showing a predominantly mononuclear infiltrate and a trophozoite (arrow). 400X. C) Necrotic area with several trophozoites (arrows) of the xenic E. histolytica (strain EGG). 400X. D) Bacterial abscess caused by inoculation of ADO bacterial flora. Normal parenchyma (nor) has a lesion limited by a fibroid wall (fib) enclosing pyocites (pi). $100 \mathrm{X}$.

Monoxenic E. dispar cultures did not cause lesions in hamster livers, even when higher concentrations $\left(5.0 \times 10^{5}\right)$ of trophozoites were used. Hamsters inoculated with the monoxenic E. histolytica presented lesions when $5.0 \times 10^{5}$ trophozoites were inoculated, but not with $2.5 \times 10^{5}$ (Table 2).

\section{DISCUSSION}

The two isolates obtained in this study, identified as E. dispar by $\mathrm{PCR}$ and isoenzyme typing, were monoxenized in YI-S medium, which has been demonstrated as being appropriate for this species ${ }^{15}$. Unlike previous reports showing zymodeme alterations after modification of the cultivation system ${ }^{1,17,18,26}$, monoxenization did not affect this parameter in our E. dispar isolates. 
COSTA, A.O.; GOMES, M.A.; ROCHA, O.A. \& SILVA, E.F. - Pathogenicity of Entamoeba dispar under xenic and monoxenic cultivation compared to a virulent E. histolytica. Rev. Inst. Med. trop. S. Paulo, 48(5): 245-250, 2006.

Table 2

Intra-hepatic inoculation of hamsters with Entamoeba dispar and E. histolytica under xenic and monoxenic cultivation

\begin{tabular}{|c|c|c|c|c|c|c|c|c|c|}
\hline \multirow[t]{3}{*}{ Strains } & \multicolumn{7}{|c|}{ Xenic } & \multicolumn{2}{|c|}{ Monoxenic } \\
\hline & \multirow{2}{*}{$\begin{array}{l}\text { Prevalence }^{\mathrm{a}} \\
2.5 \times 10^{5} \text { troph. }\end{array}$} & \multicolumn{6}{|c|}{ Grade $^{\mathrm{b}}$} & \multicolumn{2}{|c|}{ Prevalence $^{\mathrm{a}}$} \\
\hline & & 0 & I & II & III & IV & Average & $2.5 \times 10^{5}$ troph. & $5.0 \times 10^{5}$ troph. \\
\hline $\mathrm{ADO}$ & $8 / 8(100)$ & 0 & 1 & 1 & 1 & 5 & 3.25 & $0 / 5(0)$ & $0 / 4(0)$ \\
\hline ADOA3 & $3 / 6(50)$ & 3 & 1 & 0 & 2 & 0 & 1.17 & $0 / 4(0)$ & $0 / 4(0)$ \\
\hline ADOB3 & 2/7 (29) & 5 & 0 & 0 & 2 & 0 & 0.86 & $0 / 4(0)$ & $0 / 4(0)$ \\
\hline $\mathrm{MGL}_{2}$ & $5 / 5(100)$ & 0 & 0 & 0 & 0 & 5 & 4.00 & $0 / 5(0)$ & $0 / 4(0)$ \\
\hline $\mathrm{MGL}_{2}{ }_{2} \mathrm{~A} 3$ & $4 / 7(57)$ & 3 & 1 & 1 & 2 & 0 & 1.29 & $0 / 4(0)$ & $0 / 4(0)$ \\
\hline EGG & $6 / 6(100)$ & 0 & 1 & 0 & 0 & 5 & 3.50 & $0 / 6(0)$ & $4 / 4(100)^{\mathrm{c}}$ \\
\hline
\end{tabular}

a - Prevalence: number of animals with lesions divided by number of animals inoculated, also expressed as percentage; $b$ - Lesion grade evaluated as follows: 0 - Normal liver or bacterial lesion less than $4 \mathrm{~mm}$ in diameter (absence of amoebae confirmed by inoculation of a fragment in culture medium); $\mathrm{I}$ - Primary lesion at the site of inoculation, less than $15 \mathrm{~mm}$ in diameter; II - Primary lesion larger than $15 \mathrm{~mm}$ in diameter, no metastasis; II - Lesion in primary lobe, some metastasis to other areas of liver; IV - Large primary lesion, extensive metastasis, minimum of 50\% of liver involved; c - Three animals with lesion in primary lobe, some metastasis to other areas of liver (grade III) and one animal with primary lesion at the site of inoculation, less than $15 \mathrm{~mm}$ in diameter (grade I).

When it comes to the clinical form of the ADO strain carrier, other causes for the symptoms - such as pathogenic bacteria, virus and Blastocystis hominis - should be considered. The latter has been associated to symptoms in some infections ${ }^{21}$ and was detected in the parasitological examination of the patient (data not shown). However, considering that the isolation of strains with nonpathogenic zymodeme from symptomatic patients has already been described in Brazil ${ }^{2}$, the hypothesis that the symptoms could be due to E. dispar ought not to be discarded. More clinical and biological studies are necessary in order to further investigate such possibility.

The E. dispar growth in monoxenic cultivation was clearly lower than the E. histolytica strain utilized for comparison. Maximal density obtained for $E$. dispar occurred in one of the experimental repetitions of ADO strain, which reached 9,000 trophozoites/mL at 72 hours (data not shown). This density was six times lower than the density of $E$. histolytica EGG at the same time. Some hypothesis suggested explaining the difficulty in axenizing $E$. dispar strains are the inability of trophozoites to obtain enough nutrients through pinocytose or their lower tolerance to toxic metabolites produced in the medium ${ }^{7}$. These characteristics could also explain the lower duration time of the $E$. dispar growth curves in monoxenic cultivation, compared to the $E$. histolytica.

As expected, E. histolytica exhibited high lytic activity and caused lesions in hamster livers, regardless the cultivation condition. Hepatic lesions by monoxenic $E$. histolytica were induced only when inocula containing the highest concentrations of the parasite were used, suggesting a decrease in virulence in vivo due to axenic cultivation. The phenomenon has usually been observed in studies with axenic $E$. histolytica cultures $^{16}$.

When monoxenic E. dispar were tested, biological tests were practically negative. Concerning to the hepatic inoculation, we also used $10^{6}$ trophozoites of the parental monoxenic strains ADO and MGL2 (data not shown) and obtained no lesion whatsoever. These results are similar to those of ESPINOSA-CANTELLANO et al. ${ }^{12}$, who showed that an axenic E. dispar was unable to cause lesions in hamster livers.
Therefore, the monoxenic cultures can exhibit behavior similar to the axenic ones. Since axenization is a time-consuming and difficult process and Crithidia fasciculata has no pathogenic effect, monoxenic cultures could be an alternative for the biological evaluation of $E$. dispar in the absence of bacteria.

Nevertheless, the interaction of trophozoites and bacteria must be considered in the determination of the pathogenic potential of $E$. dispar. In our experiments, the cytopathic effect of $E$. dispar was moderate for xenic cultures, in contrast to the absent or minimal destruction when monoxenic strains or bacteria were used alone. Differences in results obtained from parental and cloned cultures had also occurred in the hepatic inoculation test, and can indicate population variability, which has already been detected in E. histolytica ${ }^{20}$. No correlation was found between the in vitro and in vivo assays with xenic $E$. dispar, suggesting that the mechanisms of pathogenicity in vivo can be quite different from the in vitro ones when bacteria are present in the culture.

Concerning the hepatic inoculation, the prominent lesions induced by xenic $E$. dispar could not be attributed only to associated bacteria, since bacterial flora alone did not cause important lesion. Thus, a synergistic effect between $E$. dispar and bacteria must be considered. Presence of inflammatory cells around the necrotic foci, lysis of these cells by trophozoites and release of lytic enzymes could be involved in the tissue damage. This mechanism has been shown in experimental hepatic amoebiasis induced by axenic E. histolytica ${ }^{25}$. Another report also showed the migration of inflammatory cells around trophozoites in the hepatic parenchyma inoculated with an axenic E. dispar ${ }^{12}$, but no necrotic lesion was developed. In our experiments, it is possible that the presence of bacteria could enhance the inflammatory process, maintaining a propitious environment that allows trophozoites to multiply and spread along the hepatic parenchyma.

Although E. dispar cannot cause invasive disease to man, the experimental induction of lesions in animals is a way to access its pathogenic potential. Previous reports showed the ability of xenic strains with nonpathogenic zymodeme in causing lesions in hamster liver ${ }^{5,19}$. Our studies evaluated quantitatively not only the prevalence, but also 
the degree of the lesion, showing that some E. dispar can experimentally cause severe tissue damage in vivo as that caused by a virulent $E$. histolytica. It remains to be investigated whether the pathogenic potential of some strains of $E$. dispar is enough to determine symptoms on the human host.

\section{RESUMO}

\section{Patogenicidade de Entamoeba dispar em cultivo polixênico e monoxênico comparada a uma cepa virulenta de $\boldsymbol{E}$. histolytica}

Dois isolados de Entamoeba dispar em cultivo polixênico e culturas clonadas deles obtidas foram submetidos à monoxenização utilizando Crithidia fasciculata como organismo associado. O crescimento em cultivo monoxênico dos isolados e clones, bem como sua capacidade de destruir células VERO (efeito citopático) e de produzir lesões hepáticas em hamster foram comparados a uma cepa virulenta de $E$. histolytica. Os trofozoítos de E. dispar em cultivo monoxênico apresentaram um crescimento nitidamente menor que o de $E$. histolytica e foram avirulentos tanto no teste in vivo quanto in vitro. Entretanto, isolados e clones de E. dispar em cultivo polixênico exibiram uma atividade lítica moderada sobre as células VERO (1,5 to $41,8 \%$ de destruição) e causaram lesões hepáticas em hamster (29 a 100\% em prevalência e 0,86 a 4,00 no grau de lesão) tão extensas quanto aquelas causadas pela $E$. histolytica. Embora E. dispar não seja associada à doença invasiva no homem, a ocorrência de lesões teciduais significativas, causadas por trofozoítos em condições experimentais, indica que esta espécie pode apresentar potencial patogênico considerável quando em presença de bactérias intestinais.

\section{ACKNOWLEDGMENTS}

This work was supported by Conselho Nacional de Desenvolvimento Científico e Tecnológico (CNPq) and Fundação de Amparo à Pesquisa do Estado de Minas Gerais (FAPEMIG). We thank João da Costa Viana and Edna Maria Pires for their technical assistance. Part of the results reported here was presented at the XIV Seminar on Amebiasis held in Mexico City, November 27-30, 2000.

\section{REFERENCES}

1. ANDREWS, B.J.; MENTZONI, L. \& BJORVATN, B. - Zymodeme conversion of isolates of Entamoeba histolytica. Trans. roy. Soc. trop. Med. Hyg., 84: 63-65, 1990.

2. BARRAL DE MARTINEZ, A.M.; GOMES, M.A.; VIANA, J.C.; ROMANHA, A.J. \& SILVA, E.F.- Isoenzyme profile as parameter to differentiate pathogenic strains of Entamoeba histolytica in Brazil. Rev. Inst. Med. trop. S. Paulo, 38: 407-412, 1996.

3. BRACHA, R. \& MIRELMAN, D. - Virulence of Entamoeba histolytica: effects of bacteria, micro aerobic conditions and metronidazole. J. exp. Med., 160: 353-368, 1984.

4. BRUMPT, E. - Étude sommaire de l'Entamoeba dispar n. sp. amibe à kystes quadrinucleés, parasite de l'homme. Bull. Acad. Med. (Paris), 94: 943-952, 1925.

5. BURCHARD, G.D. \& MIRELMAN, D. - Entamoeba histolytica: virulence potential and sensitivity to metronidazole and emetine of four isolates possessing nonpathogenic zymodemes. Exp. Parasit., 66: 231-242, 1988.

6. CHADEE, K.; SMITH, J.M. \& MEEROVITCH, E. - Entamoeba histolytica: electrophoretic isoenzyme patterns of strains and their virulence in the cecum of gerbils (Meriones unguiculatus). Amer. J. trop. Med. Hyg., 34: 870-878, 1985.
7. CLARK, C.G. - Axenic cultivation of Entamoeba dispar Brumpt 1925, Entamoeba insolita Geiman and Wichterman 1937 and Entamoeba ranarum Grassi 1879. J. eukariot. Microbiol., 42: 590-593, 1995.

8. DIAMOND, L.S. \& CLARK, C.G. - A redescription of Entamoeba histolytica Schaudinn, 1903 (Emended Walker, 1911) separating it from Entamoeba dispar Brumpt, 1925. J. eukariot. Microbiol., 40: 340-344, 1993.

9. DIAMOND, L.S.; CLARK, C.G. \& CUNNICK, C.C. - YI-S, a casein-free medium for axenic cultivation of Entamoeba histolytica, related Entamoeba, Giardia intestinalis and Trichomonas vaginalis. J. eukariot. Microbiol., 42: 277-278, 1995.

10. DIAMOND, L.S.; PHILLIPS, B.P. \& BARTGIS, I.L.- A comparison of the virulence of nine strains of axenically cultivated Entamoeba histolytica in hamster liver. Arch. Invest. méd. (Méx.), 5(suppl. 2): 423-426, 1974.

11. ESPiNOSA-CANTEllanO, M.; GONZALES-ROBLES, A.; CHAVEZ, B. et al. Entamoeba dispar: ultrastructure, surface properties and cytopathic effect. J. eukariot. Microbiol., 45: 265-272, 1998.

12. ESPINOSA-CANTELLANO, M.; CASTAÑON-GUTIERREZ, G. \& MARTINEZPALOMO, A. - In vivo pathogenesis of Entamoeba dispar. Arch. med. Res., 28(suppl.): S204-S206, 1997.

13. FELIX-SILVA, E. \& MAYRINK, W. - Estudos sobre a Entamoeba moshkovskii. II. Novos focos em diversos tipos de coleções hídricas no Brasil e no Uruguai. Rev. Inst. Med. trop. S. Paulo, 16: 203-221, 1974.

14. GOMES, M.A.; PESQUERO, J.B.; FURST, C. et al. - An improved method to distinguish Entamoeba histolytica and Entamoeba dispar. Parasitology, 119: 359-362, 1999.

15. KOBAYASHI, S.; IMAI, E.; TACHIBANA, H.; FUJIWARA, T. \& TAKEUCHI T. Entamoeba dispar: cultivation with sterilized Crithidia fasciculata. J. eukariot. Microbiol., 45: 3S-8S, 1998.

16. MARTINEZ-PALOMO, A. - Parasite factors of virulence. In: MARTINEZ-PALOMO, A., ed. The Biology of Entamoeba histolytica. London, John Wiley \& Sons, 1986. p. $95-98$.

17. MIRELMAN, D.; BRACHA, R.; WEXLER, A. \& CHAYEN, A. - Changes in isoenzyme patterns of a cloned culture of nonpathogenic Entamoeba histolytica during axenization. Infect. Immun., 54: 827-832, 1986.

18. MUKHERJEE, R.M.; BHOL, K.C.; MEHRA, S.; MAITRA, T.K. \& JALAN, K.N. Zymodeme alteration of Entamoeba histolytica isolates under varying conditions. Trans. roy. Soc. trop. Med. Hyg., 87: 490-491, 1993.

19. MUKHERJEE, R.M.; MAZUMDAR, M.; MAITRA, T.K. \& JALAN, K.N. - Virulence of nonpathogenic zymodemes of Entamoeba histolytica isolates from asymptomatic subjects in Calcutta, India. Braz. J. med. biol. Res., 25: 899-903, 1992.

20. OROZCO, E.; SUAREZ, M.E. \& SANCHEZ, T. - Differences in adhesion, phagocytosis and virulence of clones from Entamoeba histolytica, strain HM1-IMSS. Int. J. Parasit., 15: 655-660, 1985.

21. ROSSIGNOL, J.F.; KABIL, S.M.; SAID, M.; SAMIR, H. \& YOUNIS, A.M. - Effect of nitazoxanide in persistent diarrhea and enteritis associated with Blastocystis hominis. Clin. Gastroent. Hepat., 3: 987-991, 2005.

22. SARGEAUNT, P.G.; WILLIAMS, J.E. \& GREENE, J.D. - The differentiation of invasive and non-invasive Entamoeba histolytica by isoenzyme electrophoresis. Trans. roy. Soc. trop. Med. Hyg., 72: 519-521, 1978.

23. SARGEAUNT, P.G.; WILLIAMS, J.E.; BHOJNANI, R.; KUMATE, J. \& JIMENEZ, E - A review of isoenzyme characterization of Entamoeba histolytica with particular reference to pathogenic and non-pathogenic stocks isolated in Mexico. Arch. Invest. méd. (Méx.), 13(suppl. 3): 89-94, 1982. 
COSTA, A.O.; GOMES, M.A.; ROCHA, O.A. \& SILVA, E.F. - Pathogenicity of Entamoeba dispar under xenic and monoxenic cultivation compared to a virulent E. histolytica. Rev. Inst. Med. trop. S. Paulo, 48(5): 245-250, 2006.

24. SILVA, E.F.; GOMES, M.A. \& BARRAL DE MARTINEZ, A.M. - Entamoeba histolytica: axenization and characterization of isolated samples from symptomatic an asymptomatic patients from different regions of Brazil. Arch. med. Res., 28 (suppl.) S288-S289, 1997.

25. TSUTSUMI, V.; MENA-LOPEZ, R.; ANAYA-VELASQUEZ, F. \& MARTINEZ PALOMO, A. - Cellular bases of experimental amebic liver abscess formation. Amer J. Path., 117: 81-91, 1984

26. VARGAS, M.A. \& OROZCO, E. - Entamoeba histolytica: changes in the zymodeme of cloned nonpathogenic trophozoites cultured under different conditions. Parasit. Res., 79: 353-356, 1993
27. VOHRA, H.; BHATTI, H.S.; GANGULY, N.K. \& MAHAJAN, R.C. - Virulence of pathogenic and non-pathogenic zymodemes of Entamoeba histolytica (Indian strains) in guinea pigs. Trans. roy. Soc. trop. Med. Hyg., 83: 648-650, 1989.

28. WHO/PAHO/UNESCO - Report of a Consultation of Experts on Amoebiasis. Mexico City, WHO/PAHO/UNESCO, 1997.

Received: 15 March 2006

Accepted: 7 June 2006 